\title{
Impact of Authoritative Parenting Style on Self-Esteem among Primary School Students
}

\author{
${ }^{1}$ Adnan Hussain, ${ }^{2}$ Dr. Shazia Khalid, ${ }^{3}$ Saba Zer Naz, ${ }^{4}$ Muhammad Meikail, ${ }^{5}$ Ahmad Ullah, ${ }^{6}$ Andleeb \\ $\mathbf{1 , 2 , 3 , 4}$ Preston University Islamabad Campus, ${ }^{\mathbf{5 , 6}}$ Elementary and Secondary Education KP, Pakistan.
}

\begin{tabular}{lll}
\multicolumn{3}{l}{ Article Information } \\
Received & $:$ & 02 May 2020 \\
Revised & $:$ & 21 May 2020 \\
Accepted & $:$ & 01June 2020 \\
Published & $:$ & 10 June 2020
\end{tabular}

Corresponding Author:

Adnan Hussein

Email: Addihussain137@gmail.com

\begin{abstract}
The aim of the present study was to investigate the impact of authoritative parenting style on self-esteem. For this purpose it was hypothesized that there is a positive relationship between authoritative parenting style and self-esteem among primary school students. It was also hypothesized that authoritative parenting style positively predicts Self-esteem among primary school students. The sample comprised of 259 students, including 198 boys and 61 girls. These were recruited through convenient sampling technique from Shabqadar, district Charsadda, K.P. Pakistan. The student's age ranged from 10 years to 12 years, and their educational level was 4th and 5th classes. For data collection two scales were used. Rosenberg self-esteem scale Urdu version for measuring self-esteem of students, which was originally constructed by Rosenberg in 1965 and translated by Sammer in 2016 with 0.77 internal consistencies and test retest reliability, is 0.85 . The second scale was Parental Authority Questionnaire. That was originally constructed by Buri in 1991, and translated by Khalid in 2004, with .82 Cornbrach's coefficient and Testretest reliability is .78 . Pearson correlation result indicated significant and positive correlation was obtained between maternal and paternal parenting style and self-esteem $\mathrm{p}<0.01^{*}$. Regression analysis demonstrates $p<0.01^{*}$ between parenting style and self-esteem $\beta=.16$. Hence it is concluded that authoritative parenting style fosters self-esteem of students at primary level.
\end{abstract}

Keywords: Authoritative parenting style, Paternal, Maternal, Self-esteem.

Copyright (C) 2020: Adnan Hussain. This is an open access distribution, and reproduction in any medium, provided Access article distributed under the Creative Commons Attribution License the original work is properly cited License, which permits unrestricted use.

Citation: Adnan Hussain, Dr. Shazia Khalid, Saba Zer Naz, Muhammad Meikail, Ahmad Ullah, Andleeb. "Impact of Authoritative Parenting Style on Self-Esteem among Primary School Students, "Journal of Science, Computing and Engineering Research, 1(2), 25-30, May-June 2020.

\section{INTRODUCTION}

According to old wisdom "family is the first school for children, and parents are powerful role models". A website My Etymology Published an article in 2008 and elaborated that, Parenting is derived from Latin verb 'Parere' means to "bring forth or produce". Parents play an important role in child development (Holden, 2010). Parents' wants to see their children happy and confident but personality of these parents make them vulnerable to a specific parenting style. Parenting style is an emotional circumstance, in which parents foster their children and characterize by all aspects of parental responsibilities and demanding (Darling \& Steinberg, 1993). Preschool children raised by their parents of different parenting styles, which are varied in their degree of social competence [2]. Parents affect child out comes which in turn effect quality of citizens, so parenting style is very important [4]. Inadequate parenting style is often responsible for youth crimes, truancy etc. [6]. Family background plays a great role in determining the life of a person [7]. Parenting style is a Psychological construct that represents standard strategies that parents use in the rearing of their children [6] "Authoritative parenting is a strategy to seek reasonable rules and guidelines that are in the best interest of child". These parents are accessible and approachable parents. They give freedom to their children, to little bit extent. These parents are warm, supportive and considerate. Authoritative parenting style is responsible for high self-esteem as compared to other parenting styles. Authoritative parents are more likely to buildup self-esteem in their children. Researchers find out that self-esteem can be improved and foster by authoritative parenting style. Present study aims to investigate the impacts of authoritative parenting style on self-esteem among primary school students on the basis of literature review. Self-esteem may be defined as a person's negative or positive attitude towards him or herself defined self-esteem as an overall positive self-evaluation. Self-Esteem can be developed and changes through a person beliefs and knowledge of their thinking, actions and feelings [11]. Self-esteem is the basic human motivation and it comes on the top in the hierarchy of needs [11] and suggested the relationship between selfesteem and parenting style. According to them, authoritative parenting style links with high self-esteem, whereas authoritarian parenting style related to low self-esteem. In India and Pakistan father is generally physically more distant than mother, and father-child relationship is marked by obedience and compliance, whereas mother mostly remain busy in taking care of their children. While in many countries there is diversity in parenting style [9] the main focus of early 21 st century is the student's parenting style. 
The foundation of self-esteem develops in early life. He explained that parental involvement, acceptance, support and exposure to definite limit have greater effects on their self-esteem. Development of self-esteem differs at different stages of life. Although individual are differ in particular trajectory they follow, however, researches suggests that self-esteem level increases from adolescence to middle adulthood age and at the age of 15 years, it is at peak and then decreasing at old age rapidly. Men have higher level of self-esteem than women however, there is no such effect of gender on the developmental process, and men and women have to show the developmental process of self-esteem from adolescent to old age [22].

Authoritative parents are linked with higher level of selfesteem. Supportive parents can affect the developmental stressors and lead to positive self-esteem level Parental support, empathy, and bonding develop youth self-esteem level Poorer relationship of parents with their children can lead to lower level of self-esteem, which in turn lead to depressed mood. The way of communication of parents can affect self-esteem level and emotional competency [14]. Self-esteem is demonstrated through feelings despairs, pride, shame and alike [18]. To prepare the children, selfesteem helps them in facing challenging situations and coping with problems [20]. Students with high self-esteem are more motivated to complete even a difficult task as compared to students with lower self-esteem. Self-esteem is an important element of good academic performance, especially for male students. Present study aims to increase better understanding about parenting style, especially authoritative parenting style, and their effects on self-esteem among primary school level. Different types of parenting style have different developmental effects on adolescents. Importance of the study is to increase the awareness of students and public about parenting style and its impacts on children self-esteem. The study was conducted to find out the impacts of authoritative parenting style on self-esteem among primary school students and to find out gender differences with respect to self-esteem.

Objective of the research is to determine the impacts of authoritative parenting style on self-esteem of primary school. And provide an elaborate understanding to parents, teachers and students about these. To accomplish this objective it is hypothesized that there is a positive relationship among authoritative parenting style and selfesteem among primary school students. It was also hypothesized that authoritative parenting style positively predicts self-esteem among primary school students.

\section{LITERATURE REVIEW}

Self-esteem is the great attention of researchers. According to literature review, there are many factors responsible for Self-esteem. Among these, the most important is authoritative parenting style, which is focus of our present study. Definitional issue of major variables. Parenting style may be defined as the pattern of parental attitudes and behavior towards their children by which they communicate with them, and create a sense of emotions through which parents express their behaviors. In 1966 Baumrind categorize parenting style as Authoritative parenting style, authoritarian and permissive parenting style. According to her a parenting style in which parents are very demanding and supportive to their children are known as authoritative parenting style. They provide love and warmth to their children. There also verbal give and take characteristic present between parents and children and they communicate each other openly [21]. Authoritarian parenting style is less supportive and more demanding. Permissive parents are more supporting and are less demanding. A person's overall evaluation of competency towards himself or herself is known as self-esteem (Harter, 1988). It has been assessed that students with high selfesteem can learn enthusiastically, and can show better academic performance with low self-esteem [23]. It found that students with low self-esteem are passive do not take participation in the class and do not shows their capabilities. Theoretical framework for major variables. Symbolic interaction theory of parenting style suggests that people live in natural environment and communicate through symbols. This theory often used to describe developmental level of self-esteem in adolescents. This relates effects of parental attitude on self-esteem of children.

Identity theory of self-esteem demonstrates that identity comprises of different meanings, which exhibits understandings, feelings, and expectations; that are applied to the self as an occupant of a social position. These meanings works as standards in an identity control system Attachment theory, developed by Bowlby in 1969, that focuses on parent-child relationship. It describes the total interpersonal relationship among people. It focuses on the way an individual respond to hurt, threat, or separation from loved ones. It focuses on nature, significance and function of a child tie to their parents. This model concerned with protection and safety. It focuses on child-parent relationship to provide against physical and emotional security. It also emphasizes on the quality of care which can lead to sensitivity and responsiveness, and leads to secure or insecure attachment.

\section{A. Correlates of major variables}

Parenting style and Self-Esteem. A study was conducted by Zakeri and Karimour, at Shiraz University Iran in 2011. In this co-relational study, they correlate three types of parenting style with self-esteem. Acceptance envelopment and autonomy granting parenting style are directly related with high self-esteem, while self-esteem was low on students of behavioral strictness supervision parenting style. Gender difference was not meaningful in this study. In India research study conducted by exhibits that permissive and authoritative parenting style lead to high self-esteem, and have no big difference, while authoritarian parenting style cause low self-esteem. Students with permissive father have little higher self-esteem level than students with authoritative father. Study also shows that

Page 26 
there are not significant differences between boys and girls self-esteem level.

A Malaysian study conducted by this study they establish a relationship between parenting style and self-esteem. The result of this study reveals that authoritative and permissive parenting style are positively correlated with self-esteem, whereas, authoritarian parenting style is negatively correlated with self-esteem. A corresponding study they interrelate parenting style and self-esteem of adolescents. The study exhibits that indulgent parenting style has equal score as that of authoritative parenting style, and neglectful parenting style. This study revealed that authoritative parenting style is not responsible for optimum self-esteem level.

A study conducted by Wolf in 2000 on elaborating the influences of parenting style on self-esteem. This study reversed that parenting style has greater effect on selfesteem. Children practicing authoritative parenting style, having higher self-esteem level as compared to authoritarian parenting style. While children with permissive parenting style shows no significant result. Driscoll find out the connection between Parenting style and Self-Esteem. He demonstrated that self-esteem can changes through different life stages but there. According to their study self-esteem is lower at the age of 14 years. It was also demonstrated that authoritarian parenting style has low level of self-esteem as compared to students of other type of parenting style.

An Indian research was conducted to study the effects of parenting style on the self-esteem of adolescents. According to their study result, parental acceptance (authoritative parents) will have high level of self-esteem as compared to adolescents who perceiving concentration and avoidance attitude of parents. A study from Philippine demonstrated, In their study, they proposed a parental program to improve parenting style to foster child rearing. They also investigated that most of the students having authoritative parenting style. Despite of difficult handling of the students, there is a significant association between authoritative parenting style and self-esteem of children.

\section{RESEARCH METHOD}

\section{A. Statement of the problem and research questions}

Authoritative parenting style fosters high self-esteem in children Moreover Self-esteem is most important factor in one's developmental process. A few questions arise from literature review that is

1. What are the impacts of authoritative parenting style on self-esteem among primary school students?

2. What are gender differences with respect to selfesteem?

On the basis of these questions and literature review, the statement of problem under investigation is "Impact of Authoritative parenting style on self-esteem among primary school students".

\section{B. Significances of the present study}

The study provide us knowledge about authoritative parenting style that positively affects self-esteem of children among primary school students. It would be helpful to know students' self-esteem and then they can struggle to evaluate and improve one's self esteem. Study also help to aware parents about their child self-esteem and how to contribute their part in their child improvement. It also provides data for teachers to know these student's self-esteem, then they can encourage them, can evaluate them, and reduce their own strictness with that students who have low self-esteem, and can foster students with high self-esteem among students of primary. Study also provides data about selfesteem of boys and girls among primary school students. From the result of the present study institutes, educational organizations and teachers can manage and organize specific strategies. It adds more to the limited studies conducted in Pakistan on this topic. Study provides to researcher with insight on meaningful gaps in literature related to selfesteem and parenting style.

\section{Objectives}

Following objectives are formulated for the present study.

1. To investigate the impact of authoritative parenting style on self-esteem among primary school students.

2. To investigate the relationship between authoritative parenting style and self-esteem along with demographical variables (gender, education, socioeconomic status) among primary school students

\section{Hypotheses}

Hypotheses of the present study are as follows.

1. There is a positive relationship among authoritative parenting style and self-esteem among primary school students.

2. Authoritative parenting style positively predicts Selfesteem among primary school students.

3. There is significant differences between boys and girls self-esteem level of authoritative parenting style.

\section{RESEARCH DESIGN AND ANALYSIS}

\section{A. Research design}

In the present study Co-relational research design was used. Convenient sampling technique was used to collect data.

\section{B. Population and sample}

This quantitative and co-relational study was conducted in Shabqadar area K.P. Pakistan. Total data were collected from 9 different schools from various areas in Shabqadar, with the permission of Headmaster/ Headmistress/ Principal. 
Total sample was 259 students, including both boys and girls, which were recruited through convenient sampling technique. Age range of students ranges from 10 years to 12 years.

\section{Inclusion criteria}

Present study comprises of Primary level student of $4^{\text {th }}$ and $5^{\text {th }}$ class. Both genders were included. Students having age range of 10, 11 and 12 years were included. Students from government as well as private schools were included in the present study.

\section{Exclusion criteria}

Students having age range below or above 10 to 12 years were excluded. Repeaters were also excluded. Students who leave their questionnaire incomplete, also excluded.

\section{E. Tools of research}

Following instruments were used in research study.

Demographic Sheet: Demographic data sheet consists of Student Name, Father Name, Age (in years), Gender, Class, School Name, Medium of Instruction, Govt. private semi Govt. Family system, Income and Address.

Self-Esteem Scale: It was originally developed by Rosenberg in 1965, and translated by Sammar in 2015. This scale contains 10 items and 4 points likert scale. Cronbach alpha for this scale is $0.738(\mathrm{~N}=259)$.

Parental Authority Questionnaire: This scale was originally developed by Buri, in 1991, and translated by Khalid in 2004.This scale is divided into further two subscales, Parents Authority Questionnaire for father, and Parents Authority Questionnaire for mother. Both subscales have 30 questions of 5 level likert scales. Cronbach alpha for father authority questionnaire for authoritative father subscale is 0.741 and that is for maternal authoritative subscale is $0.717(\mathrm{~N}=259)$.

Procedure: Data was collected from different Government and private schools in Shabqader. Permission was taken from headmasters and principals of the schools. $1^{\text {st }}$ of all rapport was developed, consent was taken, and after that students are briefed about the purpose and nature of the research. Selected participants were carried in a separate class and briefed about scale and each item on the scale. For collecting data from those students they were instructed to fill the questionnaire completely and honestly. Students were assured that all information which we got from them will be used only for research purposes. After completing and collecting questionnaire, those subjects and principals of the schools were thanked.

Data Analysis: Data was analyzed by using Statistical packages of Social Science (SPSS). Co-relational index T-

test and regression were calculated. Product of both authoritative father and mother also calculated and then find the regression in a regression model.

\section{F. Limitations}

Data were collected from 259 students, from nine different schools at Shabqadar area. Boarding schools were excluded, only day schools are included. Data were collected from children through questionnaire and not from parents. Present study just focusing on parenting style and self-esteem; whereas other factors, such as students learning style, role of teachers, school environment, peer pressure etc. were avoided. There is no balance ratio of boys and girls. Students who cannot fill completely all the questionnaires, were excluded. Students who have died any of their parents or both of their parents were excluded Results

Table 1: Psychometric analysis of major variables

\section{Variables}

\begin{tabular}{ccc} 
Variables & mean & $\begin{array}{c}\text { standard } \\
\text { deviations }\end{array}$ \\
& & \\
\hline $\begin{array}{c}\text { Self-esteem } \\
\text { Authoritative father }\end{array}$ & 19.9459 & 4.48738 \\
Authoritative mother & 41.5753 & 6.75088 \\
& & 5.93481
\end{tabular}

Table 1 demonstrates psychometric analysis of the study, which include mean and standard deviation. Mean of selfesteem is 19.94 which indicates that most of the students have an average level of self-esteem. Mean of authoritative father is 40.2 and that of authoritative mother is 41.6 , its mean that most of the students have authoritative father as well dominant authoritative mother.

Table 2: Correlation among major variables

Serial

Style

I II

III

Number

\begin{tabular}{|c|c|c|c|c|}
\hline $\bar{I}$ & $\begin{array}{l}\text { Maternal } \\
\text { Authoritative } \\
\text { Parenting Style }\end{array}$ & - & $.54 * *$ & $.22 * *$ \\
\hline II & $\begin{array}{l}\text { Paternal } \\
\text { Authoritative } \\
\text { Parenting Style }\end{array}$ & & - & $.20 * *$ \\
\hline III & Self-Esteem & & & - \\
\hline
\end{tabular}

Note: $p<0.01 * *$.

Table 2 reveals correlation among major variables. The correlation is positive and significant among Authoritative Father, Authoritative Mother and Self-esteem. Correlation between both parenting style (authoritative father and authoritative mother) is significant at $0.01 * *$ level. Thus it proves the first hypothesis that "there is a positive relationship among authoritative parenting style and self- 
esteem among primary school students" i.e. authoritative father as well as authoritative mother may lead to high level of self-esteem.

Table 3: Authoritative parents as a predicator of Self-esteem

\begin{tabular}{|c|c|c|c|c|}
\hline \multirow[t]{2}{*}{ Variables } & \multirow[t]{2}{*}{$\boldsymbol{\beta}$} & \multirow[t]{2}{*}{ S.E } & \multicolumn{2}{|c|}{$95 \% \mathrm{CI}$} \\
\hline & & & $\mathbf{U L}$ & $\mathbf{L L}$ \\
\hline Constant & & 3.95 & 8.86 & $\begin{array}{c}- \\
16.19\end{array}$ \\
\hline Authoritative Father & .106 & .04 & .02 & .15 \\
\hline Authoritative mother & .166 & .05 & .01 & .21 \\
\hline $\begin{array}{l}\text { Authoritative father } \\
\mathrm{X} \text { authoritative } \\
\text { mother }\end{array}$ & .26 & 3.95 & .001 & .004 \\
\hline $\mathrm{R}$ & .24 & & & \\
\hline R Square & .058 & & & \\
\hline $\mathrm{F}$ & $18.61 * *$ & & & \\
\hline
\end{tabular}

Note: $P<0.01 * *$

To prove that authoritative parenting style including both mother and father, is the best predicator of self-esteem, the above table reveals and explain that concept and results, which is significant at $0.01 * *$ level. So it proves that authoritative father as well as authoritative mother is the best predicator of self-esteem in primary school students. This result also supports our second hypothesis.

Table 4: T-test of self-esteem with other demographic variables

\begin{tabular}{|c|c|c|c|c|c|c|c|}
\hline & & $\mathbf{N}$ & $\mathbf{M}$ & SD & $\mathbf{T}$ & Sig & $\mathbf{F}$ \\
\hline \multirow{2}{*}{$\begin{array}{l}\text { Gende } \\
\mathrm{r}\end{array}$} & Male & 198 & 19.94 & 4.53 & 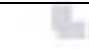 & $x=$ & 1 \\
\hline & Female & 61 & 19.40 & $\begin{array}{c}4.36 \\
5\end{array}$ & .065 & $\begin{array}{c}0.94 \\
8\end{array}$ & $\begin{array}{c}0.0 \\
2\end{array}$ \\
\hline \multirow{2}{*}{$\begin{array}{l}\text { Mediu } \\
\text { m Of } \\
\text { Instruc } \\
\text { tion }\end{array}$} & Urdu & 153 & 19.68 & 4.68 & & & \\
\hline & $\begin{array}{l}\text { Englis } \\
\mathrm{h}\end{array}$ & 106 & 20.30 & 3.87 & $\begin{array}{l}-1.0 \\
98\end{array}$ & 0.27 & $\begin{array}{c}0.9 \\
1\end{array}$ \\
\hline \multirow{2}{*}{$\begin{array}{l}\text { Family } \\
\text { Syste } \\
\mathrm{m}\end{array}$} & Joint & 106 & 19.21 & 4 & & & \\
\hline & $\begin{array}{l}\text { Separa } \\
\text { te }\end{array}$ & 153 & 20.44 & 4.73 & -2.1 & 0.03 & $\begin{array}{c}0.3 \\
9\end{array}$ \\
\hline \multirow[t]{2}{*}{ Class } & $4^{\text {th }}$ & 113 & 19.65 & 4.28 & & & \\
\hline & $5^{\text {th }}$ & 146 & 20.16 & 4.64 & _.91 & 0.36 & $\begin{array}{c}0.1 \\
7\end{array}$ \\
\hline
\end{tabular}

Note: $\mathrm{p}<0.05^{*}$
Table 4 reveals that there is no significant differences between the self-esteem level of girls and boys. It also demonstrates that medium of instruction and class level also have no differences in their self-esteem level. While family system shows significant differences between joint and separated family system at $0.05 *$ level.

\section{CONCLUSION}

\section{A. Conclusion}

The result demonstrated with the help of spss, solves all our questions and tests hypotheses. the result obtained from collected data, reveals that self-esteem and authoritative father as well as authoritative mother are inter-related with each other. findings from hong, et, a, demonstrated that authoritative parenting style is positively correlated with self-esteem in both gender. Motvaliyan work also demonstrates that authoritative parenting style and selfesteem are inter-related with each other, and have a significant relationship with each other. Leykam contradicts present study results and suggest that correlation between authoritative parents and self-esteem are not significant. Present study finding also suggests that authoritative parents can lead to high level of self-esteem at primary school level. munyi demonstrated that authoritative parenting style is responsible for high self-esteem. Wolf also suggests that children with authoritative parenting style has higher selfesteem level. martinzet, al., contradicts our results and demonstrated that authoritative parenting style is not responsible for optimum self-esteem level at brazil. Findings from sona, demonstrated that authoritative parenting style have no significant effect on self-esteem. Result shows that there is no difference between self-esteem level of girls and boys. Pandey also explains the same results that there is no main differences between boys and girls, self-esteem's level. A study by Zakeri and Karimpour demonstrated that gender differences have no meaningful relationship. Zakeri and Karimour, at Shiraz University demonstrated that there is no significant relationship between boys and girls self-esteem level.

\section{B. Suggestions and Recommendations}

From findings of the study, The Permissive parents are best for self-esteem, following by authoritative parenting style. But most of the researchers suggest that authoritative parents are best parents of all the three or four type of parents. That are due to some other factors, including child obedience, not involve in crimes, etc. so parents ought to keep their children under best rearing pattern, which would be including best characters from permissive and authoritative parenting styles. Such as to avoid their children from bad symposiums (environments), explains the causes of their punishments, do not be so strict, give explaining their view point freely, give them a friendly environment, try to fulfill their needs, do not demands of difficult and uneasy tasks, give them equal chances of sharing their thoughts in domestic problems, don't force them for any

Page 29 
type of task, give explanation of their questions, explain them all of their daily routine tasks, and try to solve all their problems. Teachers ought to come with patience with all type of primary level students, especially to those who belong to authoritarian parenting or neglectful parenting style. Keep in limits, students of permissive parenting styles and involve them in different tasks, to avoid bulling etc. Elder siblings ought to help primary level brothers and sisters in their homework and give encouragement and enthusiasm to them. It is also recommended for researcher to check the impacts of intelligent quotient of the students and educational level of parents with authoritative parenting style and self-esteem and vice versa.

\section{REFERENCES}

[1] Alsheikh, N. O., Parameswaran, G., \&Ethoweris, H. Parenting style, self-esteem and student performance in the United Arab Emirates. Current issues in education, 13(1), 2010. ISSN 1099839X.

[2] Baumrind, D., Effects of authoritative parental control on child behavior. University of California, 2003. Barkeley.Fromhttp://persweb.wabash.edu/facstaff/hortonr/articles $\% 20$ for\%20class/baumrind.pdf

[3] Bibi, F., Chaudhry, A. G., Awan, E. A., \& Tariq, B. Contribution of Parenting Style in life domain of Children. IOSR Journal Of Humanities And Social Science (IOSR-JHSS), 12(2), 91-95.2013 e-ISSN: 2279-0845.

[4] Blattner, M. C., Liang, B., Lund, T., \& Spencer, R. Searching for a sense of purpose: The role of parents and effects on selfesteem among female adolescents. Journal of Adolescence, 36(5), 839-848. 2013.

[5] Branden, N. Role of self-esteem. From http://www.nathanielbranden.com/your-role-in-your-childs-selfesteem, 1991.

[6] Branden, N. Power of Self Esteem. Barnes \& Noble Books. ISBN 1-55874-213-1. Health Communication, inc. F,D. 1992. From: http://www.nathanielbranden.com/your-role-in-your-childsself-esteem.

[7] Cast, A. D., \& Burke, P. J. A theory of self-esteem. Social forces, 80(3), 1041-1068. 2002. Retrieved from: https://www.researchgate.net/publication/280936182_Advice_on_ Riliability_Analysis_with_Small_Samples

[8] Chan, T. W., \& Koo, A. Parenting style and youth outcomes in the UK. European sociological review, 27(3), 385-399. 2010. DOI: 10. 1093/esr/jeq013.

[9] Deshpande, A., \&Chhabriya, M. Parenting Styles and its Effects on Adolescents' Self-Esteem. International Journal of Innovations in Engineering and Technology (IJIET), ISSN: 23191058. 310-315. (2013).

[10] Driscoll, L. C.Parenting Styles and Self-Esteem. Scripps $\begin{array}{llll}\text { Senior } & \text { Theses. } & \text { Paper } & \text { 155. From: }\end{array}$ https://scholarship.claremont.edu/scripps_theses/155

[11] Garcia, Q. P., \& Santiago, A. B. B. Parenting styles as correlates to self-esteem of underprivileged adolescents: basis for a proposed parenting skills program. International Journal of Advanced Education and Research. ISSN: 2455-5746. Impact Factor: RJIF 5.34. Volume 2; Issue 5; page No. 27-35, 2017.

[12] Hong, O. S., Long, C. S., \& Rahman, R. H. A. An analysis on the relationship between parenting styles and self-esteem of students of a university in Malaysia: A case study. Mediterranean Journal of Social Sciences, 6(4), 300, 2015.

[13] Hoskins, D. Consequences of parenting on adolescent outcomes. Societies, 4(3), 506-531, 2014.
[14]https://www.google.com/search?client=firefoxb\&ei=viEEXNy JILaY1fAP5JCkkAo\&q=Wolf $\% 2 \mathrm{C}+\mathrm{J} . \% 2 \mathrm{C}+\% 282000 \% 29 .+$ SelfKline, P. 2013

[15] Lee, Y. C. A study of relationship between parenting styles and self-esteem: self-esteem's indicator-parenting styles (Doctoral dissertation, UTAR), 2011.

[16] Martínez, I., García, J. F., \&Yubero, S. Parenting styles and adolescents' self-esteem in Brazil. Psychological reports, 100(3), 731-745, 2007.

[17] O'Connor, T. G., \& Scott, S. Parenting and outcomes for children. Joseph Rowntree Foundation. www.jrf.org.uk, 2007.

[18] Orth, U., \& Robins, R. W. The development of self-esteem. Current Directions in Psychological Science, 23(5), 381-387, 2014. [19] Sammer, A. Relationship between relational aggression and self-esteem among female school teachers: Positive and negative affective states as proactive factors. Manuscript in Preparation. 2016.

[20] Sharma, G., \& Pandey, N. Parenting styles and its effect on self-esteem of adolescents. The International Journal of Indian Psychology, 3(1), 7. ISSN 2348-5396 (e) IISSN: 2349-3429 (P). DIP: CO3113 v3/12015, 2015.

[21] Sona, T., Parenting styles and their effect on self-esteem. The effect of age, sex, and parenting styles on self-esteem in young adults.2017.

[22] Uji, M., Sakamoto, A., Adachi, K., \& Kitamura, T. The impact of authoritative, authoritarian, and permissive parenting styles on children's later mental health in Japan: Focusing on parent and child gender. Journal of child and family studies, 23(2), 293-302.2014.

[23] Wolf, J.,Self-esteem: The Influence of parenting styles. Research Online. Edith Cowan University, 2014.

[24] Zakeri, H., \&Karimpour, M. Parenting styles and self-esteem. Procedia-Social and Behavioral Sciences, 29, 758-761, 2011. 